\title{
Processing and marketing of rattan canes in Nepal
}

\author{
C. L. Chowdhary $\odot^{1 *}$ and I. C. Dutta $\odot^{2}$
}

Received : 22, August, 2021 Revised : 16, November, 2021 Accepted : 23, December, 2021 Published : 31, December, 2021

This study highlights the processing and marketing of rattan canes with reference to small and medium enterprises (SMEs). The study was designed based on the exploratory research, and was carried out in all the districts of Nepal with rattan enterprises. The main objective was to assess the processing status, supply and demand including constraints and potentialities of rattan-canes as well as their marketing practices. Systematic random sampling method was followed to take the sampling of rattan processing enterprises of CFUGs. The questionnaire survey was conducted among 35 rattan entrepreneurs cum rattan traders and ten executive committee members of CFUGs. The quantitative data was analyzed using Frequency. The study found that hanger, cradle, stools, chairs, and tables were largely manufactured items among all the rattan-cane products. The annual consumption of imported rattan from India and other countries ranged from 850 MT to 1094 MT. Nepalese rattan fulfills $30 \%$ of the total demand. The average marketing margin of rattan products was found to be $37-64 \%$. Nepalese rattan is potential to fulfill $70-80 \%$ of the total domestic demand of smaller size strands of rattan.

Key words: Competitiveness, Rattan enterprises, small and medium enterprises, supply and demand, traders

$\mathrm{R}$ attan is one of the economically high potential non-wood forest products (NWFPs) (Bystriakova et al., 2000; Belcher, 1995)contributing to biodiversity as well as local economy (Weinstock, 1983) in Nepal contributing $20-30 \%$ demand of the Nepalese rattan industries (MDBRPP/DFRS, 2010; Chowdhary \& Paudel, 2008). Overexploitation, poor forest management (Bystriakova et al., 2000)and loss of forest habitats were found to have threatened the existence of rattan in Nepal (Chowdhary, 1994; 1995; Paudel \& Chowdhary, 1996; 2005).

Most of the forest enterprises in developing countries fall under Small and Medium Enterprises (SMEs) (Elson, 2009). Community- owned forest-based enterprises are effective tool to address poverty issues by creating employment, generating income, and increasing rural livelihood options (Koirala et al., 2013). SMEs contribute in building local wealth, encouraging local entrepreneurship, enhancing social networks, promoting local stewardship of natural resources through increased cultural, social, financial and environmental accountability, and keeping indigenous knowledge, cultural values and traditions intact. Adding value to raw rattan through improved pro-poor value chain development and cleaner processing technologies could lift several millions more out of poverty, while maintaining a healthy natural resource base (INBAR, 2015). 
Rattan is marketed and used for multiple purposes including furniture frame, basketry, ropes, mats and bird cage (Sunderl and, 1999). In Nepal, major rattan products are indoor handicrafts such as chair, table, sofa set, hanger, stool, baskets and decorative items. Although rattan processing industries were confined to major cities in the past, they are now open both in the rural areas and urban peripheries. The total number of rattan processing industries were found to have reached 66 in 2005 from 42 in 1996. Presently, there are 57 processing enterprises running in Nepal (Chowdhary, 2017; Chowdhary \& Dutta, 2021); out of them, $70 \%$ are operated using raw rattan cane of Indian and other countries, and they are located in urban and semi-urban areas; rest of $30 \%$ SMEs rely on domestic rattan (Chowdhary, 2017). The main constraints of the rattan processing industries are supply of raw materials, diversification of products, and market linkages. An established rattan furniture unit creates employment and income generating opportunities for a wide range of people, and helps improve the economies of the rural communities (Benton et al., 2011). Community based rattan resource management approaches can be cost effective and reliable (Campbell \& Knowles, 2011). Rattanbased enterprises in Nepal are involved mainly in manufacture of furniture and other household items. The industry accounts for the production of more than NRs. 17 million worth of various rattan products, and has substantial market potential in urban areas of Nepal (Sharma, 2007).

Approximately $66 \%$ of the total consumption of rattan in Nepal are imported from North-East India, because the large-diameter rattans are not available in Nepal at commercial-scale. Most of the rattan firms are located in the urban cities, and have low market in the rural area (MDBRPP/ DFRS, 2010). Although the importance of bamboo and rattan as valuable resource is widely acknowledged, the exact scale of their trade is barely known. Tackling the international trade is difficult because of the lack of custom codes for bamboo and rattan. The international trade of all available products is recorded through Common Format for Transient Data Exchange (COMTRADE) which uses internationally agreed standard definitions and product coding.
In recognition of this potential, 14 new 6-digit individual codes for bamboo and rattan were introduced under the Harmonized Commodity Description and Coding System (HS) for global trade in 2007, an increase from only two species for bamboo and rattan (Benton et al., 2011). The position of rattan in the world market is expanding due to increasing demand for environmentfriendly products in Europe and the United States of America (USA). The world's rattan sector is estimated to generate global revenue of USD 10 billion annually (INBAR, 2015).

There are limited number of studies that examine their management strategies together, particularly in the context of SMEs (Mokhtar et al., 2014). Despite the initiation of rattan SMEs in the urban areas of Nepal in 1976, their status, marketing behavior, consumption of raw material, market growth, contribution in economy, constraints and opportunities are yet to be explored.

This paper identifies the market orientation of rattan SMEs, supply and demand situation of raw material, major market centers, marketing channel, and marketing margin. However, this paper does not cover technical aspects of rattan SMEs.

\section{Study areas}

The study was carried out in Kathmandu, Lalitpur, and Bhaktapur of the Valley together with the major cities viz. Mahendranagar of Kanchanur district, Tikapurand Sati Bazar of Kailali district, Gulariya and Rajapur of Bardiya district, Nepalganj and Kohalpur of Banke district,Pokhara of Kaski district, Bharatpur and Narayangarh of Chitwan district, Dharan of Sunsari district, and Kakkarvitta of Jhapa district where Rattan SMEs were located with potential market centers. Some of them were even located in the CFUGs' areas of Kailali and Bardiya districts. The study was conducted in the Fiscal Year (F. Y. ) 2017/018.

\section{Methods and material}

This study was designed based on the exploratory research. The research has explored research framework which includes the combination of marketing, enterprises and socio-economic status 
of the people. For this, simple random sampling method was followed to take the sampling of rattan SMEs and CFUGs. Sampling size was selected using the Equation developed by Yamane (1967) at 95\% confidence level. Sampling was determined from the total availability of rattan processing enterprises available in the areas. The researcher collected data through face to face and self-administered questionnaire techniques from the marketing managers or owners of rattan processing SMEs. Out of the 57 SMEs operating in Nepal, 25 (44\%)were found to be running in the Kathmandu Valley alone (11 in Kathmandu, 12 in Lalitpur and 2 in Bhaktapur districts) while the other SMEs were located in the major cities like Pokhara, Narayangarh, Bharatpur, Kakkarvitta, Nepalganj, Kohalpur, Rajapur and Tikapur. The survey was conducted within 35 SMEs (61. $4 \%)$ using proportionate random sampling. The respondents were either marketing managers or owners of the SMEs, with 7 women and 28 men.

The survey included 35 rattan processing and manufacturing SMEs, 526 households (HHs), 10 executive members of the CFUGs, and 3 Key Informant Interviewees (KIs). Two types of SMEs were selected - (i) the private rattan processing SMEs and (ii) the communitymanaged rattan forests representing all the geographical locations. Of the 35 SMEs selected, 16 were selected from the Kathmandu Valley, 4 from Kailali, 3 from Chitwan, 3 from Bardiya, 1 from Sunsari and 3 from Jhapa districts, 2 from Banke and 2 from Kaski districts, and one each from Dang and Sunsari districts. The HHs selected were from the users of the CFUGs managing rattan in their community forests. Similarly, 10 executive members of the CFUGs 3 officials from the governmental and non-governmental organizations were interviewed.

\section{Data analysis}

The qualitative data were obtained from personal observations and voice records. They were first coded into themes, and then analyzed for connections between data, concepts and theories. The quantitative data were analyzed using frequency of the SPSS 20 Software

\section{Results}

\section{Types of rattan processing industries/ enterprises}

Rattan processing enterprises are categorized into processing enterprises, selling enterprises and both manufacturing as well as selling enterprises. The processing enterprises manufacture varieties of handicrafts, and sell those only to the wholesalers while the selling enterprises only sell the products after collecting finished products from various processors. On the other hand, manufacturing and selling enterprises do both manufacturing and selling of rattan products by themselves. Altogether, there were3 (9\%) manufacturing rattan enterprises, 7 (20\%) selling enterprises, and 25 (71\%)both manufacturing and selling enterprises (Figure 1). Thus, majority of the rattan enterprises/entrepreneurs were found to be involved in manufacturing and selling the rattan products by themselves.

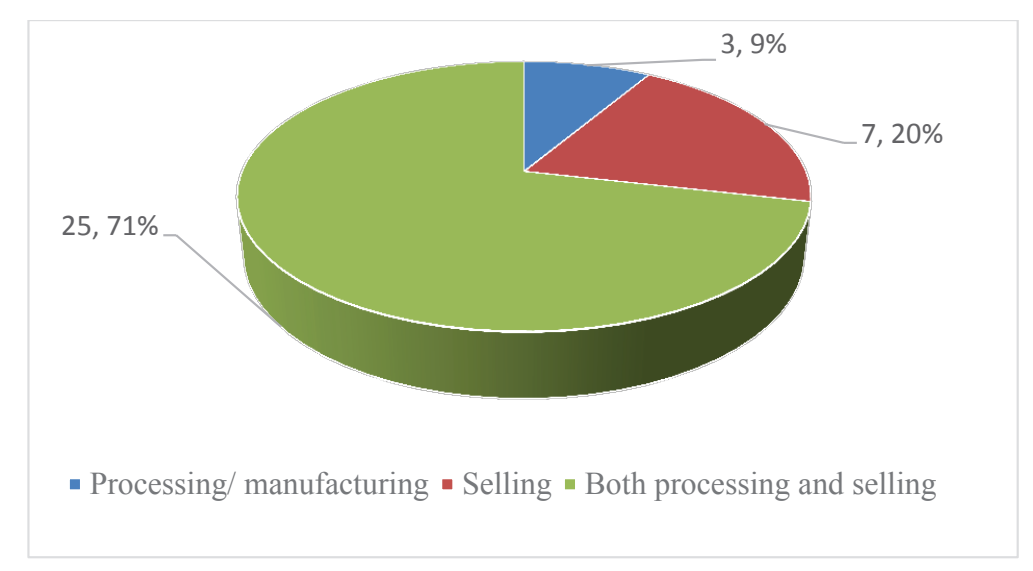

Figure. 1: Types of rattan processing industries/ enterprises 


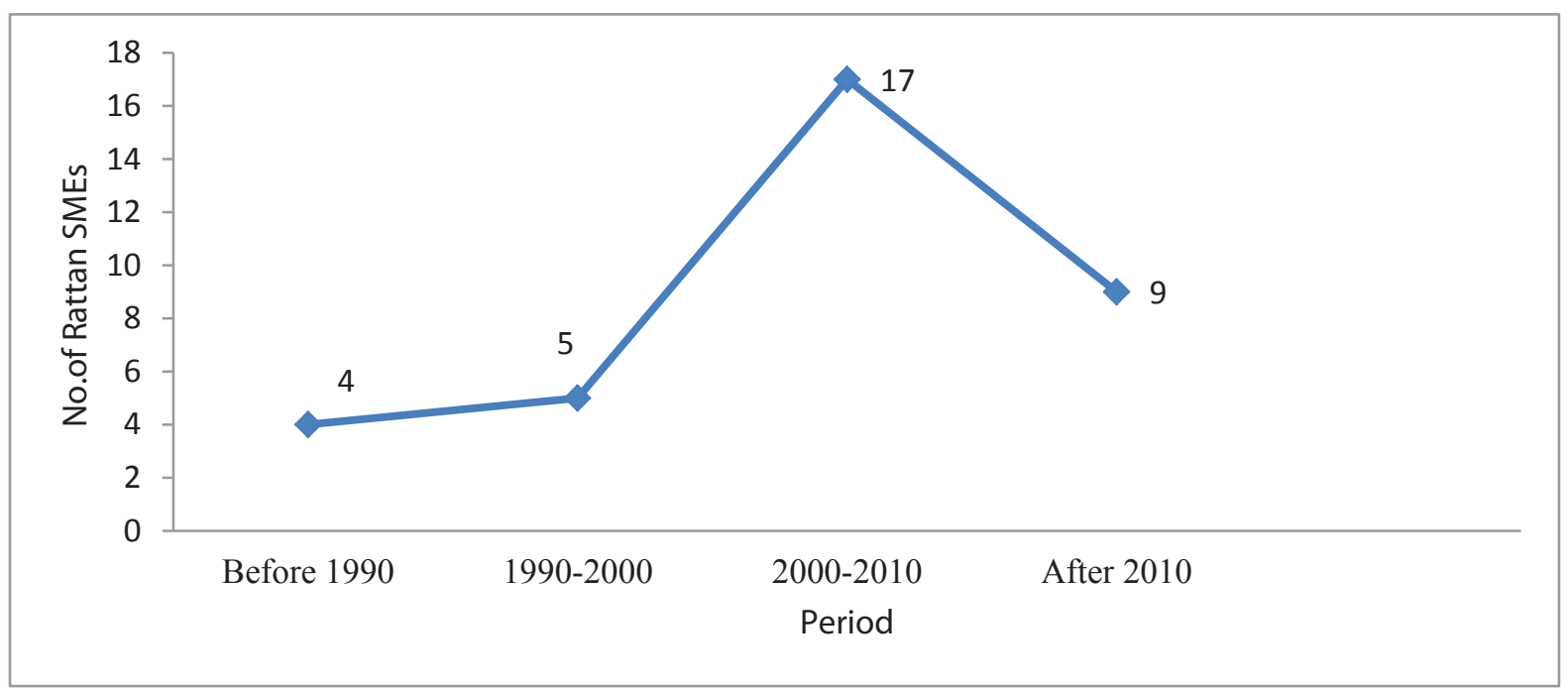

\section{Figure 2: Establishment of Rattan SMEs $(n=35)$ during different time-periods}

Out of the total 57 rattan processing industries, 25 processing industries were located in the Kathmandu Valley alone while the other processing industries were located in the major cities like Pokhara, Narayangarh, Bharatpur, Kakkarvitta, Nepalganj, Kohalpur, Rajapur and Tikapur.

The processing industries located at Birgunj, Janakpur, Rajbiraj, Itahari, and Hetauda were reported to be completely closed whereas those located in Pokhara, Nepalgunj, Kohalpur,
Biratnagar, Dharan, Bhairahawa and Butwal were reported to be partially closed (by more than $50 \%$, Figure 3). The study found that about one third $(30 \%)$ of the total demand $(2,835 \mathrm{MT})$ of unprocessed rattan cane per annum were fulfilled from its national production.

The study also found that all the 18 processing industries located in the Kathmandu Valley also used 'nigalo' (Drepanostachyum khasianum), a small-size bamboo, as an alternative raw material while producing various products. On an average,

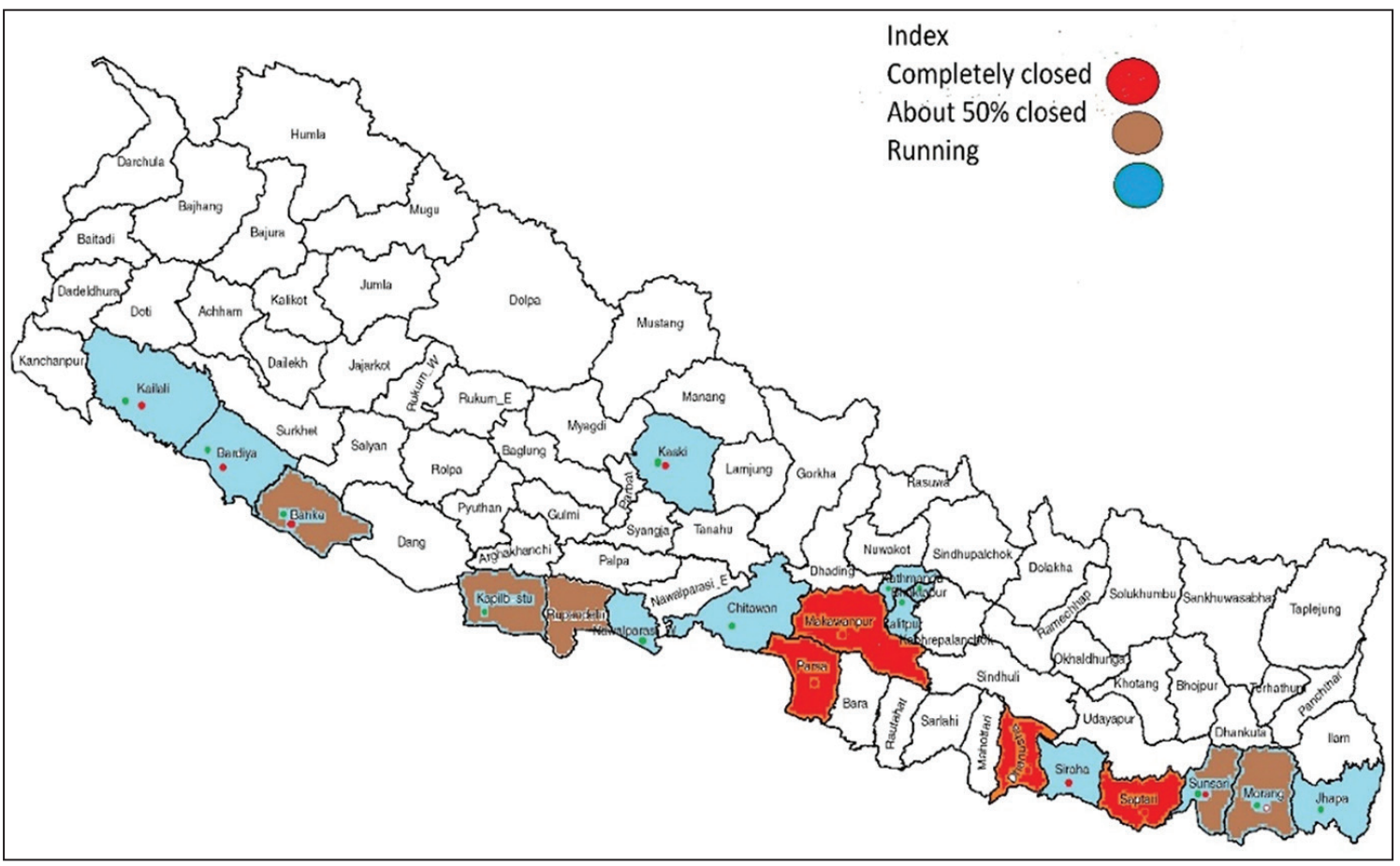

Figure 3: Distribution of Rattan SMEs showing the running, partially closed, and fully closed ones 
a processing enterprise consumed a slightly over 24,500 nigalo culms per annum (Table 1).

Table 1: Consumption of nigalo by rattan processing industries

\begin{tabular}{llll}
\hline Use of nigalo & Quantity & Value (NRs.) & Remarks \\
\hline \multirow{2}{*}{ Annual use of nigalo } & $\begin{array}{l}3,600-4,800 \text { bundles, i. } \\
\text { e. 4,000-6,000 culms }\end{array}$ & $\begin{array}{l}\text { NRs. 5-15 per culm } \\
\text { (small-size NRs. 5/culm; }\end{array}$ & 20 culms per bundle \\
large-size NRs. 15/culm) & \\
Total consumption & $102,000-340,000$ culms & NRs. 510,000-5,100,000 & \\
Average consumption & 24,555 culms & & $\begin{array}{l}\text { 17 SMEs mixed } \\
\text { nigalo with rattan }\end{array}$ \\
\hline
\end{tabular}

Source: Field Survey, F. Y. 2017/018.

The production of rattan handicrafts initiated by the CFUGs is expected to give a big boost to the industry. Currently, Nepalese artisans experimented the Nepalese rattan, Calamus tenuis, as a reliable raw material for the production of various products. There are eight rattan enterprises in Kailali and Bardiya districts using solely $C$. tenuis acquired from the local community forests. They were reported to be running within Tikapur of Kailali and Rajapur of Bardiya districts.

\section{Major rattan products}

The major rattan products were indoor handicrafts such as chairs, tables, sofa-sets, hangers, stools, baskets, cradles, stools, chairs, tables, lamp-covers, and decorative items. Among them, hangers, cradles, stools, chairs and tables were found to be the largely manufactured products whereas lamp-covers were the least-manufactured and marketed items in the processing industries. Figure 4 below presents the number and percentage of the manufacturing of rattan products of the 35 rattan processing enterprises. The rattan products,comparatively with cheaper prices and commonly used for household purpose, were the priority products of most of the processing industries. Their next priority products were the items preferred by hotels and restaurants, which indicated that the processing industries had targeted the market demand.

\section{Consumption of rattan}

The major raw materials for rattan handicrafts were solid rattan cane, Nigalo (bamboo species with small-diameter), and weaving rattan (splitone). The major rattan species consumed in the enterprises were Panibet (C. tenuis), Fekribet (C. latifolius), Gouribet (C. acanthospathus), Putalibet (C. inermis), Murgibet (C. guruba), Dudhiyabet (Daemonorops jenkinsianus), and Rotangbet/ Radanbet (C. rotang). Both the large-size and small-size rattan were mostly imported from India;however, some processing industries also imported rattan from Indonesia, Thailand, Malaysia and Singapore. Our study found that the annual consumption of the imported rattan from India and other countries ranged from $850 \mathrm{MT}$ to $1,094 \mathrm{MT}$ with the value of NRs. 60-98 million in the F. Y. 2017/018; the import of Indian rattan

Figure 4: Processing priorities of rattan products by SMEs 
Table 2: Summary of the quantities and cost of raw materials in the F. Y. 2017/018

\begin{tabular}{llll}
\hline Raw material & $\begin{array}{l}\text { Quantity (MT, on } \\
\text { an average) }\end{array}$ & $\%$ & Value (NRs. million) \\
\hline $\begin{array}{l}\text { Indian rattan } \\
\text { Malaysian, Thai, Indonesian, etc. } \\
\text { rattan }\end{array}$ & 980.00 & 66.00 & \\
Weaving (split-rattan) & 56.70 & 4.00 & $60.00-90.00$ \\
Nepali rattan & 5.75 & & $4.12-4.50$ \\
Sub-total & 445.50 & 30.00 & $4.37-5.25$ \\
Nepali rattan exported to India & $1,487.95$ & $\mathbf{1 0 0 . 0 0}$ & $\mathbf{6 8 . 4 9 - 9 9 . 7 5}$ \\
Sub-total & $1,012.50$ & & $44.55-156.70$ \\
Nigalo & $\mathbf{2 , 5 0 0 . 4 5}$ & $\mathbf{1 0 0 . 0 0}$ & $\mathbf{1 1 3 . 0 4 - 2 5 6 . 4 5}$ \\
Total & 567 & & $3.92-4.90$ \\
\hline
\end{tabular}

Source: Field Survey,F. Y. 2017/018.

alone shared about $66 \%$ of its total consumption in Nepal (Table 2).

The cost of the imported rattan canes varied depending on their diameter-size. Smaller the diameter, cheaper the price and vice versa; the cost of the imported rattan cane with smallsize diameter varied from NRs. 15 to NRs. 20 per culm and with large-size diameter ranged from NRs. 400 to NRs. 500 as compared to the domestic one costing NRs. 55 to NRs. 65 per $\mathrm{kg}$. However, the processing industries located in Kailali and Bardiya districts were reported to be fully dependent on domestic rattan. In the F. Y. 2017/018, a slightly over 1,487. 95 MT rattan canes,costing NRs. 68. 49-99. 75million were consumed by the total 57 rattan processing enterprises in Nepal (Table 2).

The Nepali rattans were extensively used in the past by the domestic rattan processing enterprises. Out of the nine rattan species recorded in Nepal, C. tenuis is mainly commercially available. However, the purchase of Nepali rattan was dramatically reduced due to administrative cumbersome from Division Forest Office (DFO), national parks and police check posts. The Indian contractors purchased Nepali rattan mainly from the CFUGs. Our survey showed that the value of Nepali rattan consumed (445. 5 MT) in the domestic market ranged from NRs. 4.37 million to NRs. 5.25 million whereas that of the exported one (to India) ranged from NRs. 44.55 million to NRs. 156.7 million.
The split-rattan is mainly used for binding purposes. The split-rattans were imported from India, Indonesia, Malaysia, and China (via Singapore). The Indian split-rattans were brought from Calcutta, Siliguri and Susta. The consumption of split-rattan was about 15 bundles $(150 \mathrm{~kg})$ per SME per annum. Our survey estimated that annually around $5,500-6,000 \mathrm{~kg}$ split-rattan costing around NRs 4.1 to 4.5 million were consumed by the rattan processing industries of Nepal in the F.Y. 2017/018 (Table 2)

\section{Supply of rattan from the Community Forests}

A Division Forest Office approves the request for harvesting various quantities of rattan from the community forests (CFs) within its territories. During the last 12 years (2005-2016), 129.96 MT with the value of NRs 12.83 million rattan were sold from the community forests of Kailali and Bardiya districts (Figure 5). After imposing Initial Environmental Examination (IEE) and Environmental Impact Assessment (EIA) in 2007, the harvesting of rattan from community forests was considerably reduced. In Bardiya district, more than 15 CFUGs had neither renewed their Forest Operational Plans (FOPs) nor carried out IEE. The concerned district forest offices approve the request for harvesting various quantities of rattan from their community forests. As a result, the local entrepreneurs did not get adequate raw material to sustain their enterprises. The entrepreneurs of Rajapur area revealed that they got $25-50 \%$ of raw rattan supply from their community forests. 


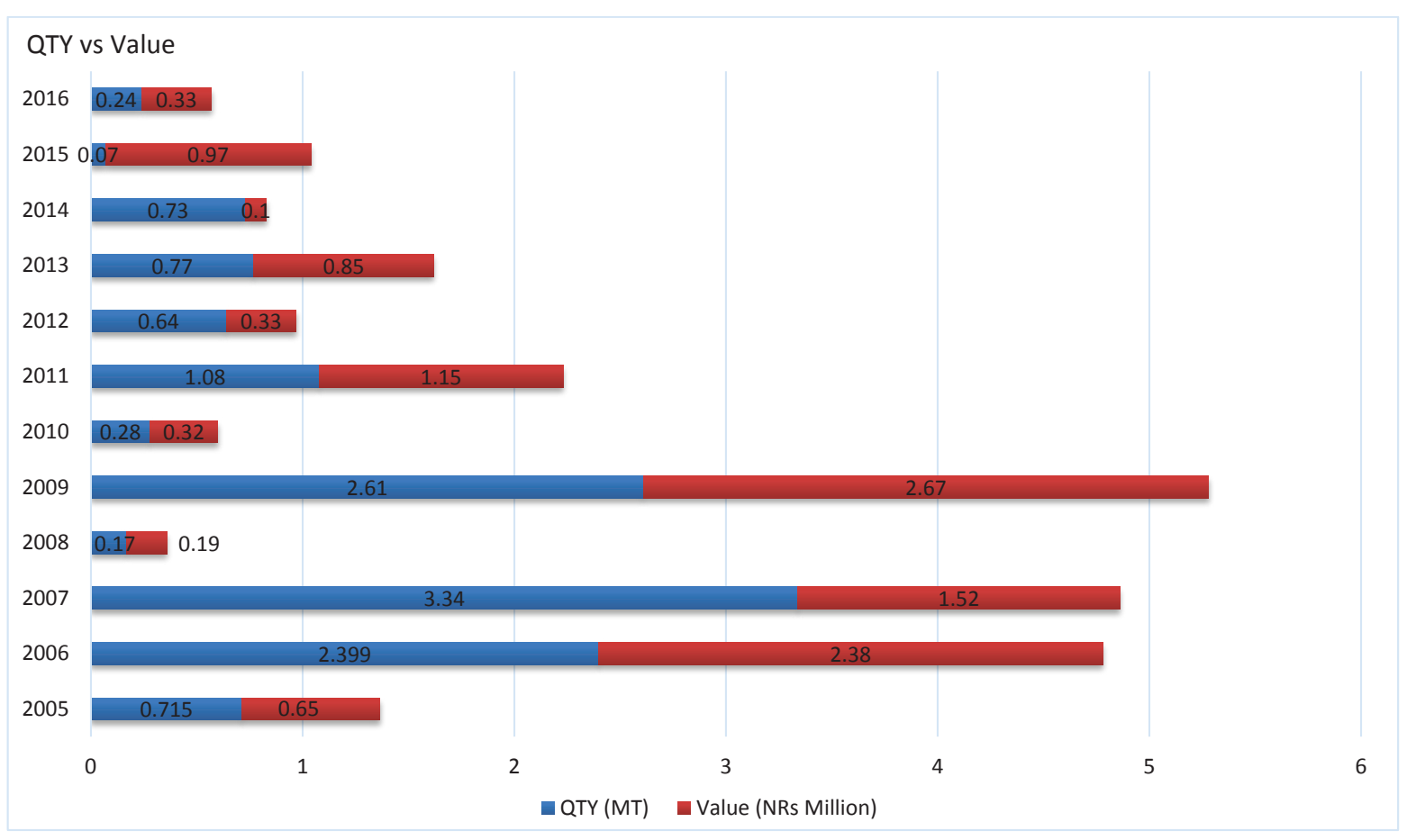

Figure 5: Qty. vs. Value (NRs. million) of rattan (in quintal) from the CFs of Kailali and Bardiya districts during 2005-2016 (Source: Field Survey, F. Y. 2017/018)

\section{Demand and supply of rattan}

According to the rattan entrepreneurs of Nepal, the total annual supply of rattan canes (both from the CFs as well as imported from the foreign countries) in the nation was estimated to be a slightly over 1,487.95 MT (see Table2). The total demand of rattan cane in Nepal, as per their version, was around 2,835 MT which indicated that the deficit of rattan cane supply was approximately 1,470.5 MT (Table 3).

The total production capacity of rattan of different community forests was about 1,418 MT per annum. However in the recent years, the potentiality of harvesting of Nepalese rattan was only $30 \%$. It indicates that $70 \%$ rattan was not harvested due to the expiry of the forest operational plans (FOPs) and administrative hurdles. Rattan forests were increased tremendously in the community forests of Nepal over the last two decades. It is estimated that the total production could increase up to4,455 MT per year if proper harvesting techniques are adopted. It could fulfill the demand of 70 to $80 \%$ rattan except the demand of largesize rattan. Large-size rattan such as C. latifolius, C. acanthospathus, and C. leptospadix are also found in many places of hilly areas. There are some 10-15 forest areas of such large-size rattan cane throughout Nepal (Chowdhary \& Paudel,

Table 3: Demand and supply of rattan

\begin{tabular}{lll}
\hline Raw material & Quantity (MT) & Average (MT) \\
\hline Total demand of rattan & $2,430-3,240$ & $2,835.0$ \\
$\begin{array}{l}\text { Deficit of rattan } \\
\text { Total capacity of production of domestic rattan (small-size } \\
\text { diameter rattan, e. g., C. tenuis), if fully regulated }\end{array}$ & $1,215-1,620$ & $1,470.5$ \\
$\begin{array}{l}\text { Total capacity of production of domestic rattan (large-size } \\
\text { diameter rattan, such as C. inermis, C. laptospadix, and }\end{array}$ & $41-81$ & $4,455.0$ \\
\begin{tabular}{l} 
C. acanthospathus \\
\hline
\end{tabular} & & 61.0 \\
\hline
\end{tabular}

Source: Field Survey, F. Y. 2017/018. 
2008). If they are properly managed, some $41-81$ MT rattan could be harvested per annum after 5 years (Table 3).

\section{Market of local rattan products}

There are five major market centers of rattan cane products in Nepal, viz. Kathmandu, Pokhara, Chitwan, Kakkarvitta and Midwest Nepal. Kathmandu is the largest market center followed by Chitwan and Pokhara. From Kathmandu, Pokhara and Chitwan market centers, rattan cane products are sold to the local people for their household purposes and also to the hotels and restaurants. There are four types of consumers of rattan cane products in Nepal, viz. i) domestic users, ii) hotels and restaurants, iii) offices, and iv) foreigners. The field survey revealed that out of the total consumption of rattan products, approximately $34.5 \%$ cane furniture were consumed by household users, $58.0 \%$ furniture consumed by hotels, restaurants, and offices, and $7.5 \%$ furniture were consumed by foreigners living in Nepal. On the other hand, high quality Nepalese furniture were also exported to Germany, America and Japan. About 50\% rattan cane products were sold in the market places of Pokhara and $30 \%$ in the market places of Chitwan. Similarly, various rattan products of different places of eastern Nepal such as Kakkarvitta sold about $60 \%$ cane products in the market places of the Kathmandu Valley and 40\%in the neighboring cities.

In the Far- and Mid-West Nepal, C. tenuis is used for furniture making. The local entrepreneurs prefer $C$. tenu is for the production of all types of furniture items such as chairs, stools, hangers, cradles, and sofasets. Hangers, stools and cradles are highly consumed by the local users. There are, altogether, 9 major market centers located in the cities of the mid-western and far-western Terai regions of Nepal, viz. Nepalgunj, Kohalpur, Surkhet, Ghorahi, Tulsipur, Tikapur, Attariya, Mahendranagar, and Dadeldhura. According to the entrepreneurs of the mid-western and farwestern Terai regions of Nepal, $30 \%$ of the total rattan products were sold in the local markets for domestic use $20 \%$ finished products were sold in the market places of the Kathmandu Valley,
$10 \%$ each in the market places of Dadeldhura, Nepalganj and Dang, and the rest $20 \%$ in the market places of Mahendranagar.

\section{Marketing channel}

Marketing channel of rattan cane highlights people, organizations and activities necessary to transfer the ownership of both Nepalese and Indian rattan from point of production to point of consumption. Indian rattan is mainly imported from Arunachal, Silapathar (Assam), Siliguri (West Bengal), Nagaland, UP and Susta (Bihar). Both small-size and large-size rattan used to be imported from these places. However, some high-quality and large-size rattan were also imported from Indonesia, Malaysia, Thailand and Bhutan too. Such high-quality rattans were utilized by only a limited processing industries of the Kathmandu Valley. The community forests of Kailali, Bardiya, Dang,and Chitwan districts were reported to have produced $C$. tenuis at commercial scale. About 233. 4 MT rattan were produced in Kailali, 32. 1 MT in Bardiya, 1 MT in Dang, and 0.5 MT in Chitwan districts.

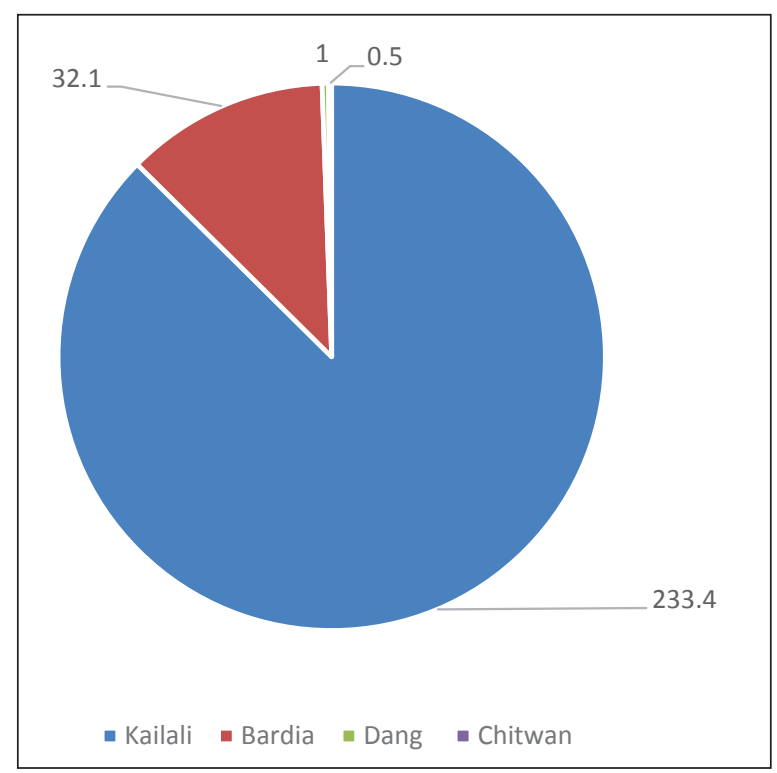

Figure 6: Quantities of rattan harvested in various districts

Although some community forests of Nawalparasi and Kapilvastu districts were also reported to have produced $C$. tenuis, their supplies were not regular and also the quantities were unknown. A few years ago, Nepalese rattan was highly 


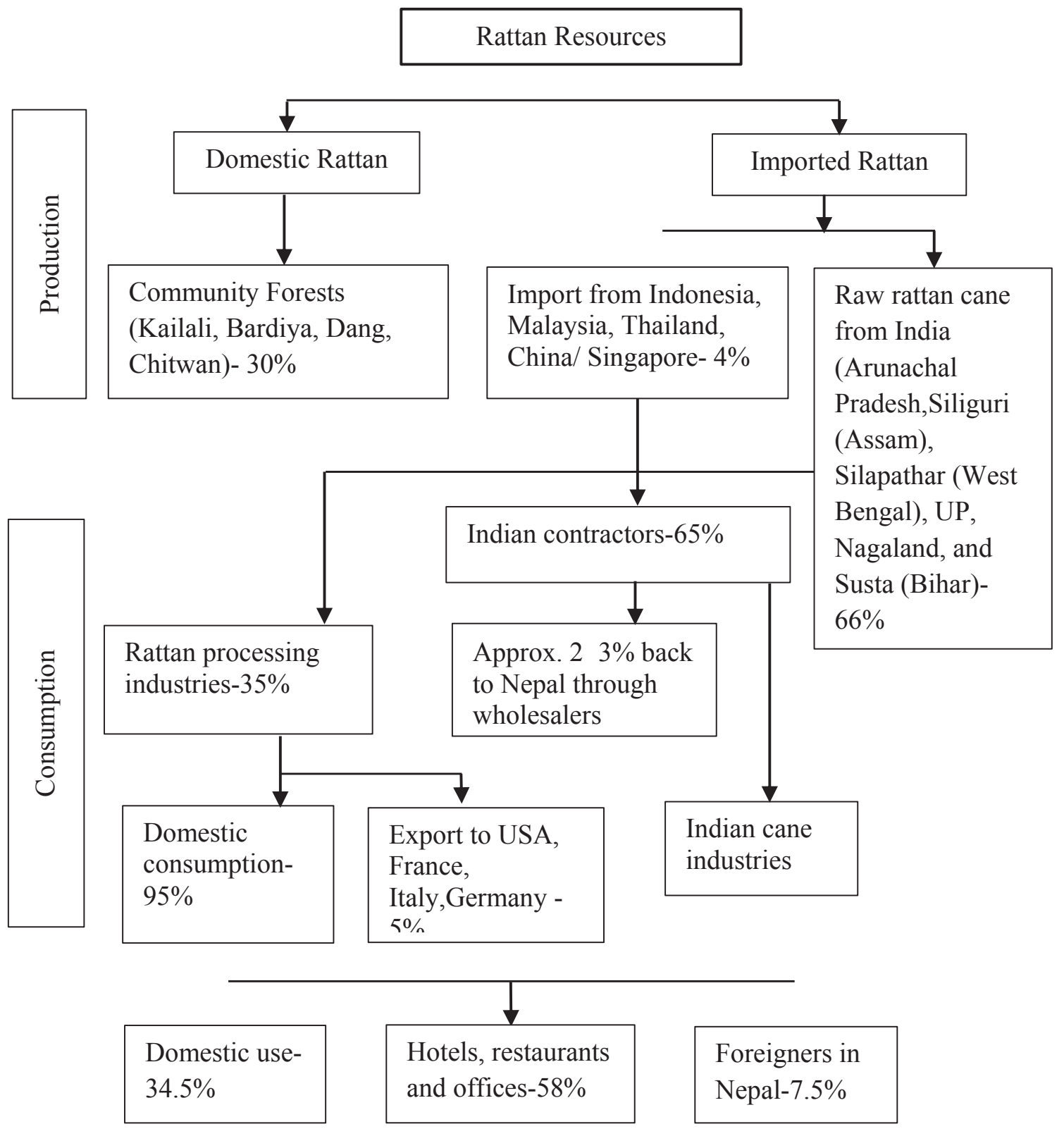

Figure 6: Marketing channel of rattan in Nepal

preferred by the processing industries of the Kathmandu Valley due to their high quality cane. It was estimated that 2-3\% Nepalese rattan mixed with Indian rattan were again brought back to Nepal from India. Split rattan was mainly imported from Indonesia, Malaysia and China through Singapore.

Of the total production of rattan cane items, $95 \%$ were consumed in Nepal and only 5\%were exported to foreign countries such as USA, Germany, Italy and France (Figure 6). Previously, rattan items was also exported to Canada and Australia.

\section{Cost of production, average selling price and marketing margin}

The cost of production of raw rattan was estimated to be NRs $28-30$ per $\mathrm{kg}$ in the community forest. This cost includes harvesting and transportation up to nearest seasoning place. However, due to shortage of rattan in the market, contractors paid higher price of raw rattan. For example, In the 


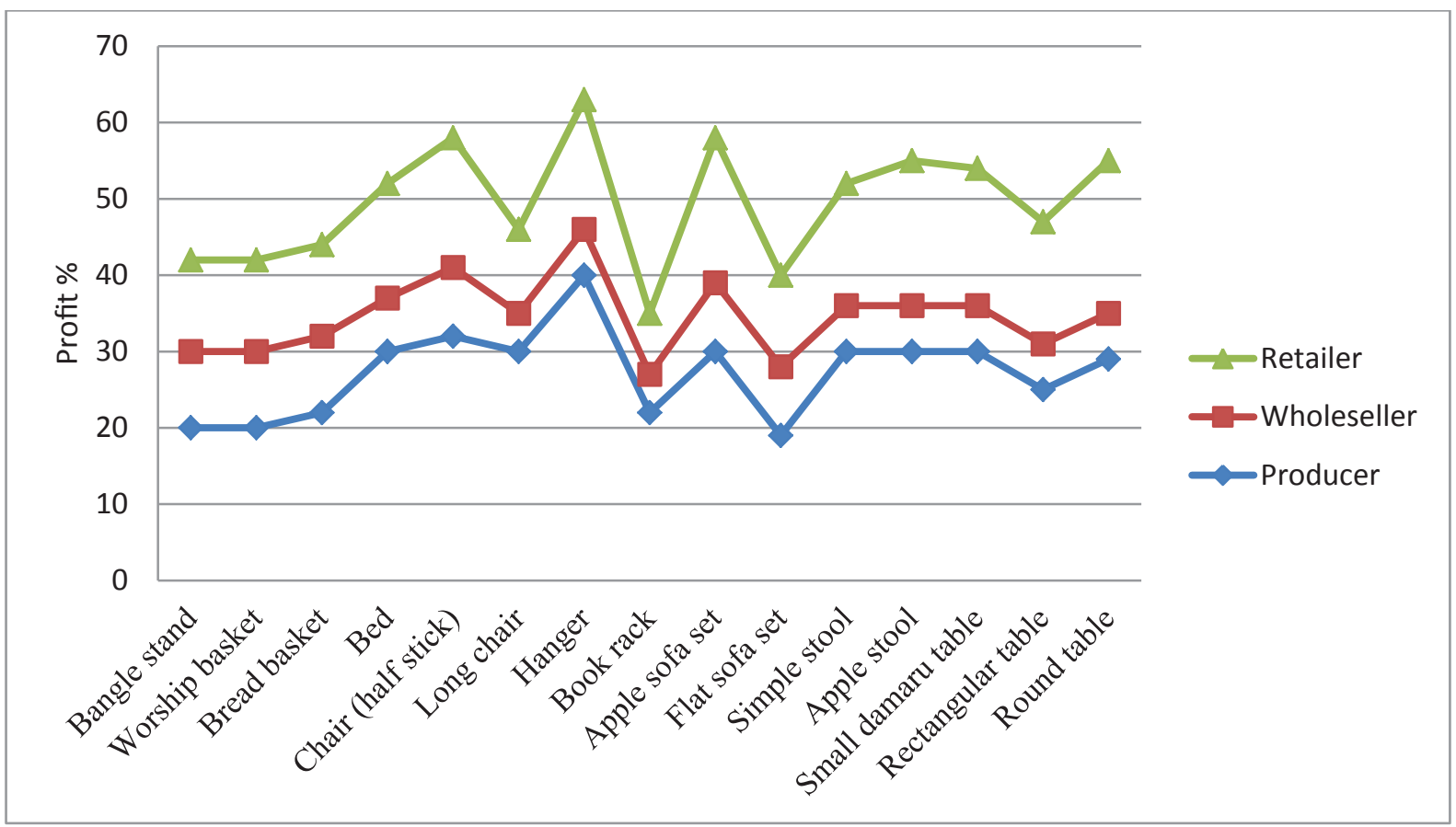

Figure 8: Marketing margin of rattan products

Kailali district, stocked rattan was sold at the rate of NRs 57 per kg in 2016.

In the case of finished products manufactured using imported rattan, the selling price might be up to $50 \%$ more than the cost price due to distance from the market centers, availability of raw material, storage capacity, and market condition. According to the entrepreneurs, if the products were immediately sold after finishing, there was likely to be $90 \%$ profit, and if stored for a longer time, there might be a chance of loss. On the other hand, nigalo-mixed items were comparatively of low cost. It was found that some of the entrepreneurs store goods in the warehouse for more than eight years since rattan products did not deteriorate even after eight years in the warehouse. Longer the period of storage of finished goods means financial flow is locked, and profit margin is less.

The marketing margin is the cost of difference between selling cost and production cost. The study found that the average marketing margin of rattan products ranged from 37 to $64 \%$. However, the normal margin was about 50\%. Figure7 presents the marketing margin based on the calculation of the cost of production and average selling price.
The benefits shared by producers, wholesalers and retailers were $18-41 \%, 5-10 \%$, and $8-20 \%$, respectively.

\section{Discussion}

Nepalese rattan processing SMEs are scattered, unorganized and less competitive in marketing. However, SMEs contribute in building local wealth, encouraging local entrepreneurship, enhancing social networks, promoting local stewardship of natural resources through increased cultural, social, financial and environmental accountability, and keeping indigenous knowledge, cultural values and traditions intact (Koirala et al., 2013). Despite the multiple-use potentialities of rattan, indoor handicrafts such as chairs, tables, sofa sets, hangers, stools, baskets, cradles, and decorative items are major rattan products in Nepal. Among them, hangers, cradles, stools, chairs and tables are largely manufactured items in the processing industries. Sunderland (1999) also argued that rattan is marketed and used for multiple purposes including making furniture frames, basketry, ropes, mats, and birdcages. According to Benton et al. (2011), producing goods from rattan creates community-based jobs, many of which are for semi-skilled labor in processing and finishing, 
which require training to increase individual's skills, and thus help empower them. Our study revealed that over the last four decades, $17 \%$ rattan processing SMEs had been closed due to irregular supply of raw material. Thapa et al. (2000) also argued in favor of this statement that the irregular supply of raw cane had caused to close $30-40 \%$ enterprises. The present study also found out that the Nepalese rattan supply fulfilled $30 \%$ of the total demand. According to Sumarno et al. (2019), the productivity of rattan furniture industry and the efforts to increase the competitiveness level of rattan products has not yet developed in Nepal although rattan industry accounts for over NRs. 17 million and there is substantial market potential in urban areas of Nepal (Sharma, 2007).

Currently, Nepalese artisans have been using $C$. tenuis as a raw material for various furniture in the local rattan processing enterprises. Currently, there are eight rattan processing enterprises in Kailali and Bardiya districts solely using C. tenuis from the local community forests. However, scarcity of raw material posed them at a risk to sustain. The initial environment examination (IEE) and environment impact assessment (EIA) processes imposed by the Government of Nepal has affected harvesting of rattan in the community forests. Before amendment of the Environmental Protection Act 2076 and the Environmental Protection Regulation 2077, the CFUGs required to conduct IEE and get approval from their respective DFOs to harvest more than $5,000 \mathrm{~kg}$. It has seriously impacted upon the harvesting of rattan (Karki \& Chowdhary, 2019). According to Sharma (2016), more than 15 CFUGs of Bardiya district had neither renewed their FOPs nor had conducted IEE. As per the amended Environmental Protection Act 2076 B. S., the CFUGs require to conduct IEE and get approval from their respective Provincial Ministries of Forest, Environment and Soil Conservation to harvest more than $150 \mathrm{MT}$ of rattan or forest products at a time (MoFE, 2021).

Importing rattan cane from India and other countries is a risky job in Nepal since export is banned by the Government of India. There are many formalities to address in the route such as check posts, local taxes, etc. during transportation. Pradhan (2015) insisted that the price of cane had been increased continuously by $10-15 \%$ per year. There are no securities and incentives to rattan processing industries from the Government of Nepal. Thapa et al. (2000) also favored the statement and argued that the price of raw cane sometimes increased 4-5 times the farm gate price. According to INBAR (2000) and Bajaj (1994), there are relatively few policies in place in most countries on bamboo and rattan, and several Asian countries have imposed bans on the export of unprocessed rattan.

\section{Conclusion and recommendation}

Rattan processing SMEs are categorized into processing enterprise, rattan selling enterprise and both manufacturing and selling enterprises. The main constraints regarding the trade of rattan are supply of raw materials, diversification of products, and market linkages. Nepal has limited supply of commercial rattan canes mainly produced in community forests. Large amount of rattan are imported from India and other foreign countries. Rattan-based enterprises in Nepal are involved mainly in manufacture of furniture and other household items. Major rattan products are indoor handicrafts such as chairs tables, sofa sets, hangers, stools, baskets and decorative items. The weak supply chain of rattan from production to processing stage, and the lack of improved skills in the processors are the major problems in most of the rattan enterprises of Nepal. Nepalese youths have proved that various types of competitive rattan cane items could be manufactured using C. tenuis alone. Therefore, effective processing technologies are required to transform the youths to design rattan products using domestic rattan. Despite $C$. tenuis including other large-size rattan have potential to scale up to meet the demand of rattan processing SMEs, the government's restriction on the harvesting, transportation and uses seems to be the main obstacle for the smooth operation of these enterprises, and so the prevailing restrictions need to be removed urgently so as to sustain them. 


\section{References}

Bajaj, M. (1994). Public Policy and the Sustainable Uses of Forest Resources: A Study of the Indian Experience of Stare. M. Sc. Thesis. London: Wye College, University of London.

Belcher, B. (1995). Bamboo and Rattan Production to Consumption Sytem: A framework for assessing development options. Beijing: International Network for Bamboo and Rattan (INBAR).

Benton, A., Cronin, T., Frith, O. and Jonkhart, J. (2011). Market Potential of Bamboo and Rattan Products. Beijing: International Network for Bamboo and Rattan (INBAR).

Bystriakova, N., Dransfield, J., Kapo, V. and Lysenko, I. (2000). Potential distribution of rattans in Asia-Pacific and Africa. Cambridge: UNEP-WCMC.

Campbell, R. and Knowles, T. (2011). Project Evaluation of WWF Sustainable Rattan Project in Lao PDR. WWF Greator Mekong Lao Country Program.

Chowdhary, C. (1994). Distribution and Status of Rattan Nepals. Pokhara: Institute of Forestry.

Chowdhary, C. (1995). Partial Survey of the distribution of Rattan in Nepal. Banko Janakari, 5 (2): 82-83.

Chowdhary, C. L. (2017). Socio-economic and market study of rattan and its contribution to livelihood in Nepal. International Network for Bamboo and Rattan Organization (INBAR), Beijing. http://www. inbar. int (Accessed on January 2, 2021).

Chowdhary, C. L. and Dutta, I. (2021). Value Chain Analysis of Rattan in Nepal. Nepal Journal of Multidisciplinary Research (NJMR)4 (1): 84-97. doi:https://doi. org/10. 3126/njmr. v4i1. 36621 (Accessed on 15 October 2021).
Chowdhary, C. and Paudel, S. (2008). Rattan Cultivation, Management and Development Initiatives in Nepal. Kathmandu: Kabita and Sunita.

Elson, D. (2009). Adding value can FLEGT voluntary partnership agreement to increased investment and trade for partner countries? Forest governance, Market and Trade implications for sustainability and livelihood. London: Department for International Development.

INBAR (2000). Research needs for Bamboo and Rattan to the year 2000. Beijing: International Network for Bamboo and Rattan.

INBAR (2015). Toward a framework for rattan sector development in AEAN countries. International Network for Bamboo and Rattan. https:www. inbar. int Retrieved on 20 Decembr 2020.

Karki, M. B. and Chowdhary, C. L. (2019). Non-timber Forest Products (NTFPs) and Agroforestry Subsectors: Potential for Growth and Contribution in Agriculture Development. In A. K. Ganesh Thapa, Agriculture Transformation in Nepal: Trend, Prospects, and Policy Options. pp. 385-419. Springer Nature Singapore Pvt. Ltd.

Koirala, G., Acharya, R. P., Dhakal, S. and Karki, G. (2013). A Rapid Assessment of Forestbased enterpises in Nepal. Kathmandu: Multi-stakeholders Forestry Programme.

MDBRPP/DFRS (2010a). Market Opportunity and Constraints for Bamboo and Rattan Commodities ofNepal. MarketDevelopment of Bamboo and Rattan Products with Potential Project. Kathmandu: Department of Forest Research and Survey.

MDBRPP/DFRS. (2010b). Review of Developed Western Markets for Bamboo and Rattan Commodities of Nepal. Department of Foret Research and Survey . Kathmandu: 
Market Development of Bamboo and Rattan Products with Potential Project.

MoFE (2021). Nepal Rajpatra (Gazette of Government of Nepal). Ministry of Forests and Environment. https://doind. gov. np/ (Accessedon November 17, 2021).

Mokhtar, S., Yusoff, R. and Ahmad, A. (2014). Key elements of market orientation on Malaysian SMEs performance. International Journal of Business and Society, 15 (1): 49-64.

Paudel, S. and Chowdhary, C. (1996). Rattan of Nepal. In: M. Karki and R. Rao (eds. ). Role of Bamboo, Rattan and Medicinal Plants in Mountain Development. pp. 156-161. Pokhara: Institute of Forestry/ IDRC.

Paudel, S. and Chowdhary, C. (2005). Managing Rattan as a common property: a case study of community rattan management in Nepal. Journal of Bmaboo and Rattan4 (1): 81-91.

Pradhan, A. (2015). Perception of rattan furniture in Nepalese society. C. L. Chowdhary, (Interviewer cum Translator). August 10, 2015. Kakkarvitta, Nepal.

Sharma, D. R. (2016). Bottleneck of Rattan Business in Bardiya District. C. L. Chowdhary, (Interviewer). June 2016, 28. Gularia, Bardiya)

Sharma, U. R. (2007). Development of rattan sector under community forestry enterprise in Nepal: future direction. https://www. researchgate. net/publication/291529732 (Accessed on August 23, 2020).

Sumarno, Dharsono, Guntur, Purnomo, A. and Setyawan, B. W. (2019). Rattan Batik: Local wisdom based Rattan Furniture Finishing Industry. SEWORD FRESS.

Sunderland, T. C. (1999). New research on African rattan an important NTFP from the forest of Central Africa. The non- wood forest products of Central Africa: current research issue and prospect for conservation and sustainable development (pp. 87-98). Rome: Food and Agriculture Organization (FAO).

Thapa, H., Paudel, S. and Chowdhary, C. (2000). Identification, Validation and In-situ Conservation of Rattan in Nepal. Kathmandu, Nepal:International Network for Bamboo and Rattan (INBAR): Department of Forest Research and Survey.

Weinstock, J. (1983). Rattan: ecological balance in Borneo Rainforest Swidden. Economic Botany 37 (1): 58-68. 